University of Nebraska - Lincoln

DigitalCommons@University of Nebraska - Lincoln

2013

\title{
The modified Bruun Rule extended for landward transport
}

J.D. Rosati

U. S. Army Corps of Engineers, Julie.D.Rosati@usace.army.mil

R.G. Dean

University of Florida

T.L. Walton

Coastal Tech Corp

Follow this and additional works at: https://digitalcommons.unl.edu/usarmyresearch

Rosati, J.D.; Dean, R.G.; and Walton, T.L., "The modified Bruun Rule extended for landward transport" (2013). US Army Research. 219.

https://digitalcommons.unl.edu/usarmyresearch/219

This Article is brought to you for free and open access by the U.S. Department of Defense at DigitalCommons@University of Nebraska - Lincoln. It has been accepted for inclusion in US Army Research by an authorized administrator of DigitalCommons@University of Nebraska - Lincoln. 


\title{
The modified Bruun Rule extended for landward transport
}

\author{
J.D. Rosati ${ }^{\text {a,* }}$, R.G. Dean ${ }^{\text {b }}$, T.L. Walton ${ }^{c}$ \\ a U. S. Army Corps of Engineers, Washington, DC 20314, United States \\ b University of Florida, Gainesville, FL 32605, United States \\ c Coastal Tech Corp., Tallahassee, FL, United States
}

\section{A R T I C L E I N F O}

\section{Article history:}

Received 3 January 2013

Received in revised form 24 April 2013

Accepted 28 April 2013

Available online 13 May 2013

Communicated by J.T. Wells

\section{Keywords:}

shoreline retreat

sea level rise

overwash

equilibrium beach profile

\begin{abstract}
A B S T R A C T
The Bruun Rule (Bruun, 1954, 1962) provides a relationship between sea level rise and shoreline retreat, and has been widely applied by the engineering and scientific communities to interpret shoreline changes and to plan for possible future increases in sea level rise rates. The Bruun Rule assumes that all sand removed from the upper profile is deposited offshore as sea level rises, although overwash during storms and landward Aeolian transport clearly indicate otherwise. Herein, we examine processes associated with sandy beach evolution in response to relative sea level rise and propose a modified form of the Bruun Rule that considers the full range of parsing cross-shore transport, from completely seaward to completely landward depending on the prevailing storm and surge conditions and whether there is a surplus or deficit of sand in the profile with respect to the equilibrium beach profile. A methodology is proposed that more appropriately represents the long-term processes and beach response. However, an improved quantitative understanding of landward transport is required for optimal application of the proposed method.
\end{abstract}

Published by Elsevier B.V.

\section{Introduction}

The Bruun Rule (Bruun, 1954, 1962) provides a relationship between sea level rise and shoreline retreat that, for more than five decades, has provided the engineering and scientific communities with a useful method of interpreting shoreline changes and designing beach stabilization projects, most notably beach nourishment projects. However, attempts to verify the Bruun Rule based on field measurements have proven quantitatively inconclusive, in part due to noise in the data (Schwartz, 1967, 1987; Rosen, 1978; Pilkey and Davis, 1987; Bruun, 1988; SCOR Working Group 89, 1991; List et al., 1997 among others). This, along with further examination of the associated processes, has brought attention as to whether the Bruun Rule appropriately represents evolution of sandy beaches to relative sea level.

The Bruun Rule relates the shoreline retreat to the product of sea level rise and the ratio of the horizontal to vertical dimensions of the active profile. The profile is translated landward and upward without a change of form with the eroded sand from the eroded upper portions of the profile transported and deposited seaward to raise the seaward active portions of the profile by the amount of the sea level rise. This process, consisting only of seaward net sediment transport, is the feature addressed herein. A key feature of the

\footnotetext{
* Corresponding author. Tel.: +1 2027611850.

E-mail address: Julie.D.Rosati@usace.army.mil (J.D. Rosati).
}

Bruun Rule is the quantification of the seaward dimension of the offshore deposition, considered as the distance from the shoreline to the depth of closure. In their consideration of an entire barrier island response to sea level rise, Dean and Maurmeyer (1983) appear to be the first to suggest both seaward and landward transport although they did not discuss the issue in detail. They developed an equation relating barrier island retreat without a change in form to the product of sea level rise and the ratio of the horizontal and vertical dimensions of the active system. This translation resulted in both seaward and landward sediment transport. Dean and Maurmeyer did not provide a quantitative relationship between overwash volumes and shoreline retreat nor did they explicitly treat the case of overwash on a mainland as is presented herein.

In its original form, the Bruun Rule did not consider sources and sinks nor gradients in longshore transport, although it has been modified and applied to adjust for these effects. Everts (1985) developed and applied a sediment budget approach which accounted for landward and alongshore losses as well as offshore transport due to sea level rise. Davidson-Arnott (2005) considered landward transport due to shoreline response to sea level rise and further suggested that all associated transport is landward. Davidson-Arnott did not provide a relationship between shoreline retreat, sea level rise and other pertinent dimensions.

Herein, we examine processes associated with sandy beach evolution in response to relative sea level rise and propose a modified form of the Bruun Rule that considers the full range of parsing crossshore transport, from completely seaward to completely landward 
depending on the prevailing storm conditions and whether there is a surplus or deficit of sand in the profile with respect to the equilibrium beach profile. The paper is organized by first providing a brief review of the Bruun Rule and summarizing previous studies with a focus on field evaluations. We discuss fundamental concepts relating to beach response and evidence demonstrating the need to modify the Bruun Rule for landward transport. Modified Bruun Rule equations are presented followed by several example calculations. We conclude by highlighting research and data required to apply the modified Bruun Rule.

\section{The Bruun Rule}

The Bruun Rule relates the shoreline retreat, $R$, to sea level rise, $S$ by the ratio of the horizontal and vertical dimensions of the active profile, $W_{*}$, and $h_{*}+B$ respectively, see Fig. 1 and Eq. (1).

$R=S \frac{W_{*}}{h_{*}+B}$

Additionally, the Bruun Rule predicts that all of the sand eroded through profile retreat is transported seaward.

A wide range of investigations and applications of the Bruun Rule and overwash have been conducted including laboratory studies (Schwartz, 1965, 1967; Williams, 1978; Park, 2006) and numerical model applications (Kobayashi et al., 1996; Tega and Kobayashi, 2000; Donnelly et al., 2006; Donnelly, 2007, 2008; Larson et al., 2009). SCOR Working Group 89 (1991) provided an excellent broad review of the Bruun Rule and other predictive models of shoreline response to sea level rise. The SCOR study concluded "the existing laboratory and field studies have not convincingly demonstrated the validity of the Bruun Rule." Stive (2004) presented a broad and insightful examination of the processes governing profile response to sea level rise. Dubois $(1990,1992)$ questioned the omission of landward transport in the Bruun Rule and the assumption that all eroded sediments are transferred seaward. He argued that there is no evidence that sediment is transported offshore where it remains as a permanent deposit. Cooper and Pilkey (2004) argued that the Bruun Rule should be abandoned because it was based on false assumptions and field studies have disproven its applicability although they do not provide a meaningful alternative. The authors noted the widespread use of the rule world-wide, in North America, Caribbean, South America, Europe, New Zealand, Australia, Southeast Asia and the Middle East, for establishing coastal setback zones, numerical modeling, coastal evolution studies, and beach nourishment design. They recognized that the Bruun Rule addresses an important societal problem and that there is no simple, viable alternative. One limitation of the Bruun Rule discussed by Cooper and Pilkey is addressed herein: representation of overwash. Below we provide a brief review of the field studies that have been conducted of the Bruun Rule to determine its validity.

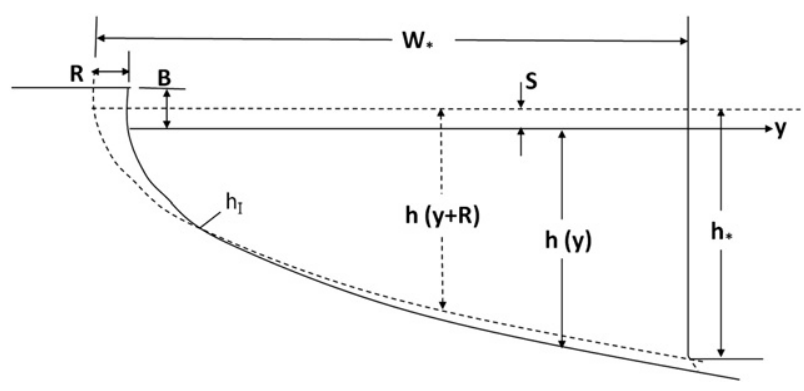

Fig. 1. Characteristics of the Bruun Rule (Bruun, 1954, 1982).
Hands $(1979,1980,1983)$ reported on observations of water level and associated shoreline changes on Lake Michigan from 1967 through 1976 during which the water level rose slightly more than $1 \mathrm{~m}$ and then fell by approximately $0.2 \mathrm{~m}$. Of the six surveys conducted, four documented rising water level and two falling water level. It was found that the general characteristics of the shoreline response were consistent with the Bruun Rule and that the calculated recession lagged the measured recession. The calculated and measured shoreline changes were in good agreement at the sixth survey which documented some recovery relative to the fifth survey.

Rosen (1978) conducted an evaluation of the Bruun Rule based on profile response in Chesapeake Bay. The total shoreline length was $338 \mathrm{~km}$ considered in 13 segments. A closure depth of $3.6 \mathrm{~m}$ was adopted for the study based on a regional slope break and earlier studies showing that sand existed primarily landward of this depth. The average measured shoreline recession rates (over 100 years) for the 13 segments were compared with those based on the Bruun Rule. It was found that the differences varied substantially ranging from $-68 \%$ to $+224 \%$; however, the average overall agreement was within $3 \%$. The largest differences were found in areas of marshy shorelines.

Mimura and Nobuoka (1995) presented results from Niigata, Japan over a period of 18 years during which ground water withdrawal resulted in relative (subsidence coupled with limited sea level rise) sea level rise rates up to $7 \mathrm{~cm} / \mathrm{yr}$. Ninety profile lines spaced at $100 \mathrm{~m}$ were surveyed 11 times during the 18 year period. Closure depths of $10 \mathrm{~m}$ and $17.5 \mathrm{~m}$ were considered. Plots show that the ratio of shoreline retreat to land subsidence is approximately 100. It was concluded that the "Bruun Rule is verified to reproduce the past shoreline retreat very well." Subsidence complicates the evaluation of the Bruun Rule due to the reduced or no offshore deposition as shown in Fig. 2.

Dean (1990) combined the average state-wide shoreline change rates for the east and Gulf coasts of the U.S. that were assembled by Dolan et al. (1983) with the available relative sea level rise rates from tide gage measurement results either in the state or nearby and presented the results in Fig. 3 in which the usual ratios of shoreline response to sea level rise 50:1 and 100:1 are also shown. It is evident that there is a large scatter in the results due, in part to the effects of inlets and other unknown factors. Regardless of the causes of the scatter, it appears that other factors are operative than those considered in the Bruun Rule. Zhang et al. (2004) criticized the quality of the shoreline change data used by Dean as being unduly affected by inlets.

Kaplin and Selivanov (1995) compared profile changes in the Caspian Sea to those calculated with the Bruun Rule and a modified form of the Rule for the period 1978/79 to 1990/91, during which water level in the Caspian Sea rose approximately 1.8-2.5 m (varied by region). The best agreement to the Bruun Rule occurred with a modified version that took into account local conditions. The authors

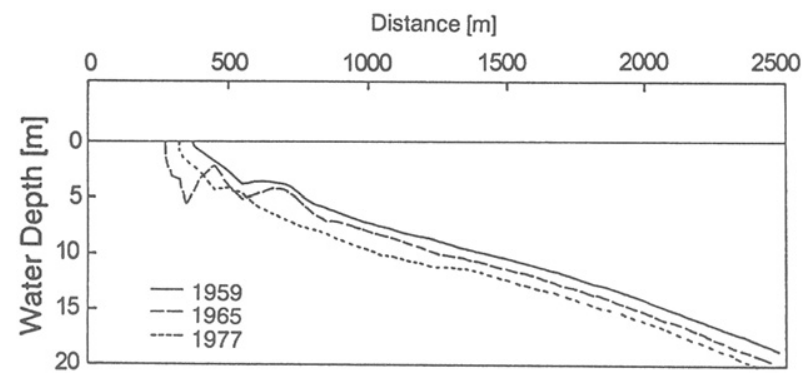

Fig. 2. Three profiles presented by Mimura and Nobuoka (1985) in their evaluation of the Bruun Rule for the Niigata, Japan area which experienced high subsidence over the study period. Note the parallel profiles for depths greater than $10 \mathrm{~m}$ supporting the choice of $10 \mathrm{~m}$ for depth of closure. 


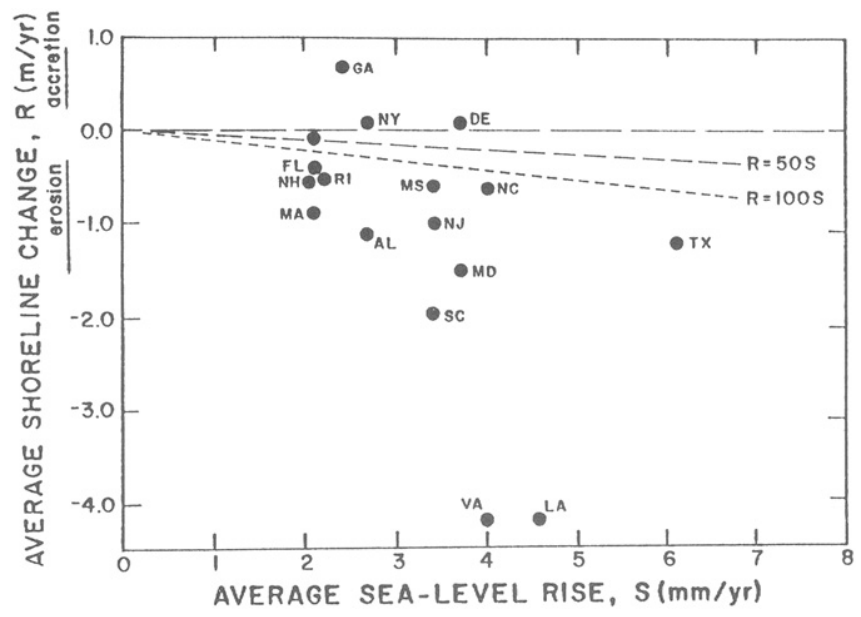

Fig. 3. State-wide shoreline change rates versus average sea level change rates for the east and Gulf coasts of the United States (Dean, 1990).

concluded that where possible, longshore transport, overwash, and Aeolian sediment transport should be included in calculations.

List et al. (1997) modified the Bruun Rule to account for fine sediments eroding from the Louisiana shoreface, and tested the utility of applying the method to hindcast erosion considering only the sandy portion of the profile. The authors applied the Bruun Rule to only those locations that met an equilibrium criterion from the $1930 \mathrm{~s}$ to 1980 s during which relative sea level rise was approximately $1 \mathrm{~cm} /$ year. For these 37 locations, they did not find a good correlation between shoreline retreat and relative sea level rise. Tarigan et al. (1996) argued that the Bruun Rule is not valid at muddy coastlines because these shores violate three fundamental tenets of the Bruun Rule: the profile exhibits a concave power law shape; the concave shape is consistent during rising sea level; and all eroded sediments are deposited within the active profile. List et al. (1997) omitted profiles that were exceptions to these tenets or modified sources and sinks to account for differences.

Leatherman et al. (2000) calculated the ratio of long-term shoreline change to relative sea level rise rates for five coastal compartments along the U.S. East coast, and limited application to those sites with alongshore uniformity. The ratios ranged from to 110 to 181 , larger on average than the 50 to 100 discussed by Bruun (1962). In reference to the Bruun Rule, the authors concluded "but the model is confirmed in that the trend is always at least two orders of magnitude greater than the rate of (relative) sea level rise."

Zhang et al. (2004) conducted a careful examination of the Bruun Rule through comparison of relative sea level rise and shoreline recession trends in the same five coastal compartments as Leatherman et al. (2000). The average recession rates were fairly small ranging from 0.13 to $0.38 \mathrm{~m} / \mathrm{yr}$, resulting in average ratios of recession to relative sea level rise varying from 50 to 120 with an average of 78 . The authors concluded that the "Bruun Rule is validated" although it was noted that for the two compartments with the lowest rates (Long Island and Delmarva Peninsula) "there is evidence in both cases that beach nourishment is occurring naturally." Additionally, consideration of contributions from overwash or Aeolian transport was not included in this study, thus it may have been more appropriate for the authors to have stated "the form of Bruun Rule is validated."

Ranasinghe et al. (2012) developed a process-based model for coastal recession that includes probabilistic estimates of sea level rise, and compared calculations to those with the Bruun Rule. In an application to Narrabeen beach, Sydney, Australia, the authors concluded that the Bruun Rule was very conservative (e.g., overestimated recession), yielding estimates for the year 2100 with less than an $8 \%$ probability of exceedance.
Absalonsen and Dean (2011) analyzed the long-term (about 140 years) shoreline changes on the east and west coasts of Florida. Although the focus was not the Bruun Rule, it was found that prior to beach nourishment (about 100 years of data), the average shoreline change rates on the east and west coasts of Florida were $+13 \mathrm{~cm} / \mathrm{yr}$ and $-7 \mathrm{~cm} / \mathrm{yr}$, respectively. Clearly the Bruun Rule does not apply on the east coast and would yield a very small recession to sea level rise ratio (about 35) for Florida's west coast. It appears that gradients in longshore sediment transport and/or sediment transport from offshore are affecting these areas.

The focus here is a more complete consideration of the processes attending sea level rise and development of relationships for shoreline retreat and sea level rise considering arbitrary proportions of seaward and landward transport volumes. In reference to nearshore response to sea level rise, Dubois (1993) replied to Bruun's (1993) discussion of Dubois (1992) "In the opinion of this writer, there is no other problem facing the community of coastal scientists and engineers that is as important as this one." We wholeheartedly agree.

\section{Discussion of processes}

Coastal processes are complex and vary with location and time, thereby inspiring humility in the investigator. Understandably, engineers and scientists have attempted to simplify and idealize these processes through models that provide a structure to facilitate understanding of forcing and response characteristics. Equilibrium beach profiles (EBPs) are an example of such a model which provides a relationship defined by a minimum number of parameters that agrees reasonably well with long-term shape of offshore beach profiles in nature. Such models are useful in testing relationships and in the design of engineering projects such as beach nourishment projects with sand characteristics different than the native sand. Bruun (1962) first developed the following monotonic equilibrium profile relationship:

$h(y)=A y^{2 / 3}$

in which $h(y)$ is the depth at a distance $y$ from the mean sea level shoreline and $A$ is a so-called profile scale parameter, with units of length raised to the one-third power and depends on sediment size, D or sediment fall velocity. Dean (1977) provided a physical interpretation of this form in which the wave energy dissipation per unit water volume is uniform across the surf zone based on linear water wave theory. Moore (1982) developed a relationship between the $A$ parameter and sediment size and Dean (1991) further provided examples of the application of this model. Inman et al. (1993) have extended this model type to the case represented by two segments of the above form but with different exponents and reference positions for the two profile segments; however, this representation requires seven parameters making it difficult to apply and test against profiles in nature. Clearly in considering models for nearshore morphology, there is a tradeoff between realism and simplicity which capture the essential underlying physics and/or characteristics.

\subsection{Two profile types}

In the following, we discuss two profile types relative to crossshore transport.

\subsubsection{Equilibrium beach profiles}

It has been suggested that the state of a beach at any given time relative to its EBP plays a dominant role in the cross-shore direction of sediment transport (e.g., de Beaumont, 1845). Specifically, if a profile has an excess of sediment relative to its EBP, and/or the sediment is coarser than specified for that EBP shape, and forcing conditions are 
sufficient to mobilize the excess sediment, then transport will be landward. Conversely, if the profile has a deficit of sediment or if the sediments are finer than indicated by the shape of the EBP, and there is sufficient energy in the system to mobilize sediment, the transport will be seaward.

Although the above is a very simple working hypothesis, it is consistent with the de Beaumont (1845) theory of barrier island formation in which formation occurs via landward transport under conditions for which there is an excess of sediment in the system. Davis (1994) stated in discussing the origin of barrier islands, "Some, perhaps most, appear to have formed as the result of some type of landward transport and upper aggradation of sands." The form of the long-term EBP depends primarily on the sediment characteristics, which for sandy beaches are a function of the regional geology that provided the sediments as well as forcing conditions that have sorted and reworked littoral material. In nature, beach profiles are dynamic, varying as a function of sediment in the system, waves, currents, winds and tides. During storm conditions, the profile adjusts to be of milder slope than is indicated by the long-term EBP. The milder slope is believed to be due to the elevated water levels as well as the nearshore wave setup with the higher waves. Additionally the width of the active nearshore zone is increased during storm conditions due to the larger waves which break farther offshore.

An exception to this discussion occurs for profiles which, due to their origin, are steeper than equilibrium such as profiles on a predominantly rocky coastline and nearshore. The profiles may be so steep as to be inconsistent with EBP formation by the sediment derived from erosion of the rocky coast. If the eroded sediment is fine sand, the steep nearshore will preclude the formation of a sandy beach. Some California coastal areas may fall in this class. Thus, the response to sea level rise on a profile that is steep and perhaps rocky will not yield a sandy beach. In addition, as discussed by Tarigan et al. (1996), the Bruun Rule does not consistently apply to cohesive beaches. These beaches that are inconsistent with EBPs are beyond the scope of this paper.

\subsubsection{Storm impact scales}

Sallenger (2000) defined four so-called "Impact Scales" depending on the wave and surge interaction with the profile. Although these scales were developed for barrier islands, they also apply more broadly to sandy coasts of interest here. In the first least severe scale (termed "swash" by Sallenger), the water level does not overtop the berm and the waves result in berm erosion, seaward sand transport and deposition forming bars. Most or all of the sands return during milder wave conditions. This profile response is also observed for seasonal winter/summer beach profiles (Shepard, 1950; Sonu, 1973; Lippman and Holman, 1990). For this scale, by definition, no net onshore sediment transport occurs and the return flow (undertow) in the surf zone contributes to the tendency for seaward sediment transport. The second impact scale (Impact Scale 2, termed "collision regime" by Sallenger) occurs with a higher water level and erosion of the dune. Sand transports offshore and alongshore and does not typically return to re-build the dune.

The third scale is of interest here (Impact Scale 3, termed "overwash" by Sallenger) and includes more extreme storms with increases of water levels and wave runup such that sand is transported landward over the berm and possibly dunes resulting in overwash deposits. However, there is no net landward flow of water. Finally, Impact Scale 4 is the "inundation regime" in which there is a net water flow over the barrier island. With net landward water flow, the return flow in the surf zone is reduced thereby facilitating landward sediment transport.

Morton and Sallenger (2003) present an extensive summary of overwash data for seven hurricanes or hurricane seasons. Individual overwash ranged from several meters to almost a kilometer. The averages for the seven cases ranged from $25 \mathrm{~m}$ to $425 \mathrm{~m}$. Overwash thickness and estimated volumes per unit beach length were presented where available. The maximum volume per unit beach length was for an individual overwash fan, $225 \mathrm{~m}^{3} / \mathrm{m}$ which is equivalent to that for a substantial beach nourishment project. In Delaware, the 1962 "Ash Wednesday" storm caused inland overwash distances of up to $650 \mathrm{~m}$ and a total overwash area of $8.34 \mathrm{~km}^{2}$ (McCarty, 2009). Following the storm, $695,000 \mathrm{~m}^{3}$ of overwash deposits were placed back on the beach. Podufaly (1962) reported typical overwash thicknesses of $1.2 \mathrm{~m}$ ranging up to $1.8 \mathrm{~m}$ during the 1962 Ash Wednesday storm. Recent overwash caused by Hurricane Sandy in October 2012 provides evidence of depositions 1 to $2 \mathrm{~m}$ in thickness along the New Jersey coast (Shaffer, 2012). With undeveloped shorelines, this sand would remain on land and is nature's way of maintaining land elevation relative to rising sea level. Thus, in this case, at least a portion of the cross-shore sediment transport is landward and under natural conditions would remain without returning to the nearshore system. This net landward transport is not accounted for in the Bruun Rule but is a key component of long-term coastal processes in response to sea level rise.

In summary, it appears that in considering nearshore response to storms, it is necessary to distinguish between impact scales that do and do not cause overwash as discussed above.

\section{Evidence of landward sediment transport during sea level rise}

In the following, we examine several processes which support landward sediment transport due to sea level rise.

\subsection{Overwash and Aeolian transport}

As noted, the Bruun Rule predicts that all sediment deposition associated with sea level rise is seaward. The well-known occurrence of overwash during major storms and the recognition that this process is necessary for the maintenance of land elevation relative to sea level rise clearly underscore the presence of net landward transport and the need to include this in a modified Bruun Rule. Aeolian transport, emphasized by Davidson-Arnott (2005), is also a process whereby landward transport occurs from the dry, unvegetated beach albeit in a more continuous manner than overwash.

As noted, overwash by wave runup and overtopping can occur for situations when the mean water level is lower than the beach berm or through wave and current induced sediment transport when the mean water level exceeds the adjacent land elevation. In the latter case of barrier island overtopping, wave and surge current strength can be substantial.

Fig. 4 presents a photograph of overwash deposits of approximately $1 \mathrm{~m}$ depth after Hurricane Isabel in 1983. Similarly, Fig. 5 presents upland profiles on Santa Rosa Island, FL after Hurricane Ivan in 2004 illustrating a case of storm surge and waves eroding and overtopping the dune resulting in overwash deposits of approximately $1.5 \mathrm{~m}$ thickness.

Khalil et al. (2006) and Khalil (2008) discussed barrier island evolution along coastal Louisiana in response to beach nourishment for sites with sand fencing constructed. Natural barriers in Louisiana are low-lying islands consisting of a thin veneer of sand that overlies fine deltaic sediments. Their low elevation relative to mean sea level and storms causes them to be overwashed regularly. With placement of beach nourishment on Timbalier Island, a sufficient quantity of dry unvegetated sediment existed such that Aeolian transport occurred. Sand fencing captured sand that might otherwise have been blown across the relatively narrow islands, and relatively large depositional features formed over a 4-month period (Fig. 6) (Khalil, 2008).

Williams (2010) documented overwash on Bolivar Peninsula, TX after Hurricane Ike in 2008 as shown in Fig. 7 for a profile taken along the axis of an oblique overwash fan. Although not uniform 


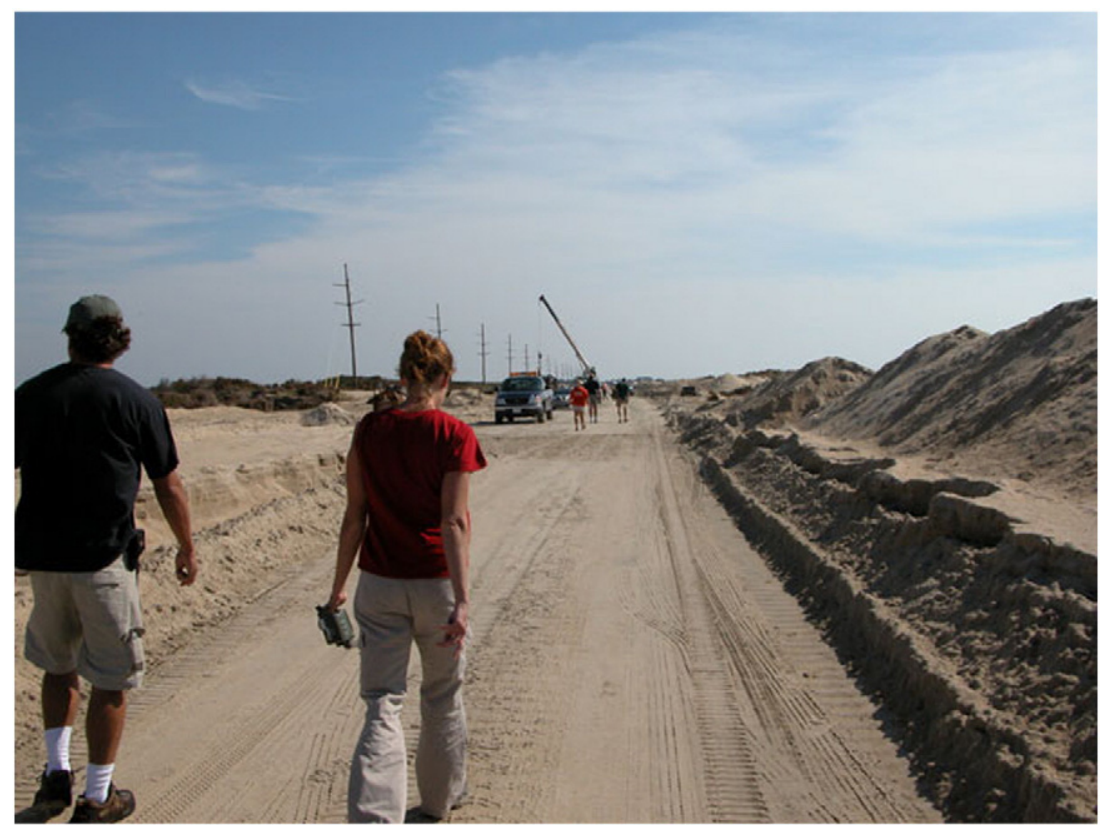

Fig. 4. Overwash deposits due to Hurricane Isabel (1983), North Carolina.

along the Bolivar Peninsula shoreline, the magnitude of this overwash was approximately $80 \mathrm{~m}^{3} / \mathrm{m}$.

\subsection{Barrier island formation due to excess of sand in profile}

In accordance with the de Beaumont theory that excess of sand in a profile will cause landward sediment transport which can either widen the beach constructing beach ridges or result in barrier islands, Fig. 8 presents a Google photograph of Cayo Costa Island south of Boca Grande Pass on the west coast of Florida. The inlet processes have resulted in an excess of sand in the south ebb tidal shoal and resulted in a small barrier island. This barrier island system is quite dynamic, waxing and waning in response to periods of mild and storm conditions, respectively. Several other similar areas exist on the lower west coast of Florida.

4.3. Lack of offshore sand deposits predicted by the Bruun Rule and sediment sorting

The Bruun Rule predicts that in response to sea level rise, sand will be transported and deposited seaward. It can be shown by considering an

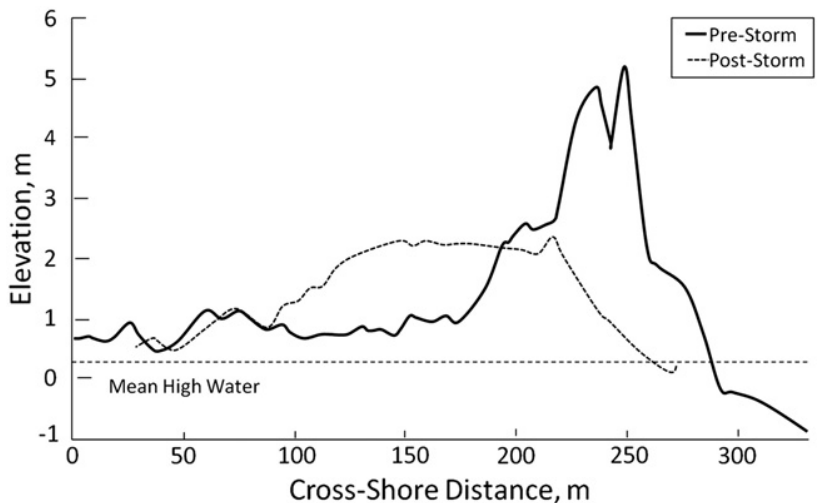

Fig. 5. Dune cross-sections on Santa Rosa Island, FL prior to and after Hurricane Ivan (2004). idealized equilibrium beach profile of the form of Eq. (2) that the final thickness of this trailing deposit seaward of the depth of closure is the difference between the depth of closure and the intersection depth of the two profiles, see Fig. 1. Consideration of profiles of the type of Eq. (2) shows that for small values of sea level rise, the intersection depth, $h_{I}$, is given by $h_{I}=\frac{4}{9} \frac{h_{*}}{\left(1+B / h_{*}\right)^{2}}$. For $B / h^{*}=1 / 3, h_{I} / h^{*}=1 / 4$. Thus, for $h_{*}=6 \mathrm{~m}$, the trailing thickness would be $0.75 h_{*}$ or $4.5 \mathrm{~m}$. Although there is a lack of complete sediment thickness information, it is clear that at many locations, at most, a veneer of sand is present overlying a mud or rocky substratum. Examples include rocky areas such as the reefed areas in Florida (Finkl et al., 2005; Robertson et al., 2008; Indian River County, Palm Beach County and others), the muddy areas off Louisiana where the barrier islands are translating rapidly landward and some are being drowned, and areas off Texas (e.g., the eastern half of Bolivar Peninsula in Jefferson County).

\subsection{Profile deepening with time}

We have found that profile surveys on the east coast of Florida indicate a lowering over time of the seaward portions of these profiles. In conjunction with the establishment of coastal regulations on predominantly sandy beach systems, Florida commenced conducting beach profile measurements in the mid-1970s. The survey technology has improved over the years with the development of GPS, digital fathometers, etc. In analyzing these data, it became obvious that the average profiles have deepened with time seaward of the hypothesized depths of closure. Procedures and results are described below.

Three profile dates were generally available for each county. The profiles were all related to the same vertical datum and depths were averaged from $6 \mathrm{~m}$ to $8 \mathrm{~m}$ and the depth averaged for successive profiles. It was found that, on average, these depths increased with time. For each of the 12 sandy shoreline counties on Florida's east coast, three profiles were selected near the middle of the county and well outside the influence of tidal inlets. The average change in depths for the offshore portions of the profiles determined as described above was calculated, and the average deepening was $0.10 \mathrm{~m}$ from the mid-survey to the earliest survey and $0.37 \mathrm{~m}$ from the latest to the earliest survey. 


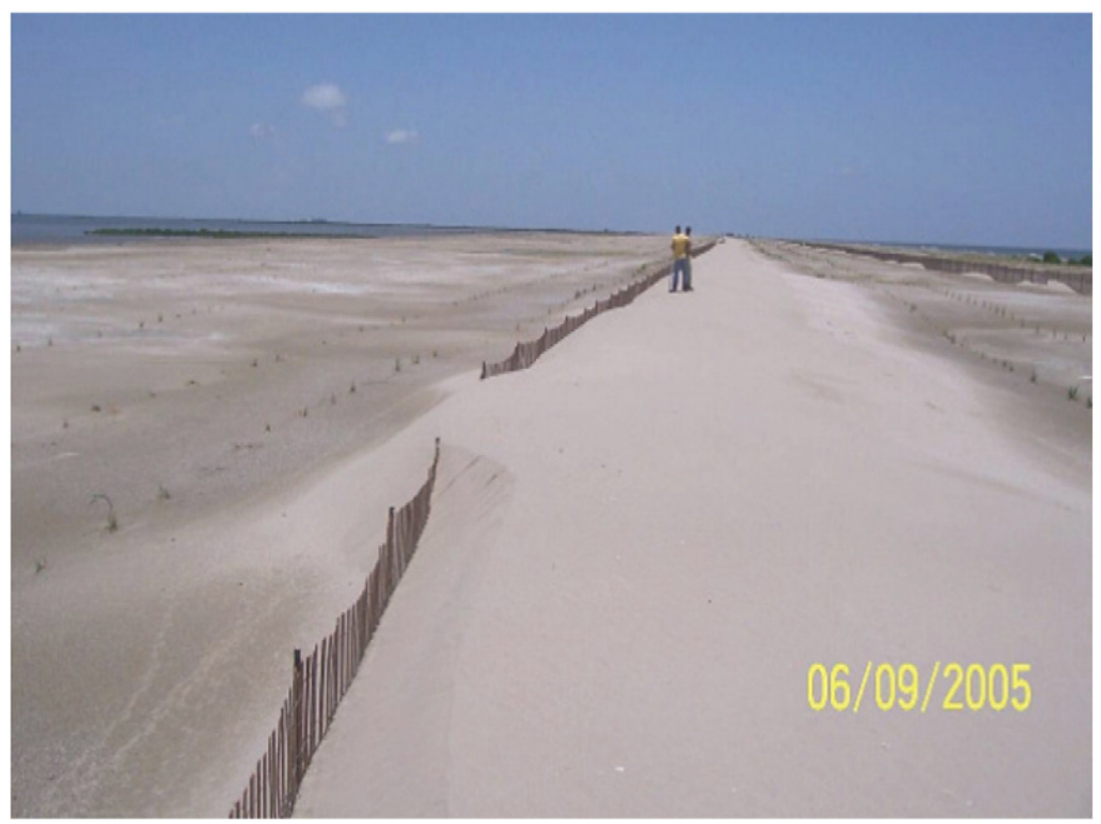

Fig. 6. Evidence of Aeolian transport following beach nourishment on Timbalier Island, Louisiana; sand was captured from December 2004 to April 2005 (Khalil, 2008 ).

Similar profile lowering was found by Leidersdorf et al. (1993, 1994) for central and southern Santa Monica Bay as shown in Fig. 9. These data ranged from 1935 to 1992 and included two major beach nourishment projects in 1947 and 1963 which amounted to $76 \%$ of the 31.6 million $\mathrm{m}^{3}$ placed. The interpretation of profile lowering by Leidersdorf et al. is:

"the bulk of the deepening occurred after 1953 and before 1975 . No major storms took place during this period, suggesting that profile adjustment in response to altered sediment characteristics is the most probable explanation."

In his application of a sediment budget approach to profiles at Smith Island, VA, Everts (1985; Fig. 4) shows offshore profile lowering at Smith Island, VA. His profiles spanned a 100 year period from 1852 to 1954.

An alternate explanation for these observations for Florida, Santa Monica Bay and Smith Island is that the surveys are in error. We have considered this possibility and have concluded that while the magnitude of deepening is uncertain considering effects of hydrographic survey noise and is variable in the longshore direction and time, the phenomenon is likely real. For the east coast of Florida, this could be due to the generally mild storm conditions with the excess of sand in the profile that was responsible for the construction of barrier islands still transporting sand landward.

\subsection{Sediment sorting}

Generally, sediment is sorted with the finer sands seaward and the coarser sands in the nearshore. Charles collected and analyzed 1165 sediment samples along the Florida east coast with the average size results varying with offshore distance as shown in Fig. 10 (reported in Dean and Charles (1994)). A literal interpretation of the Bruun Rule would suggest that, during sea level rise, the coarser sediment eroded from the berm would be transported seaward and deposited resulting in a much more uniform sediment distribution in the cross-shore direction. However, the upper panel of Fig. 10 shows that the berm sand with median size of $0.4 \mathrm{~mm}$ is not evident in the offshore sediments, with median sizes from 0.2 to $0.3 \mathrm{~mm}$. The small increase in sand size beyond a seaward distance of $500 \mathrm{~m}$ is due to the slow disintegration of calcareous reefs nearby.

\section{The Bruun Rule modified for landward transport}

Several issues have been raised and discussed in the preceding section that suggest the need to revise the Bruun Rule to include the occurrence of landward transport.

This section considers idealized profiles of the form of Eq. (2) and investigates profile response due to landward transport associated with Aeolian and/or overwash processes. We present a modified form of the Bruun Rule and the solution for profile response and volumetric transport past any location along the active profile. In this section, $y$ is the seaward distance from the initial shoreline location, the initial berm height is $B_{0}$, the depth of closure is $h_{*}$, the sea level rise is $S$, the shoreline recession is $R$, the profile scale parameter is $A$, the length and thickness of the washover deposit are $Y_{L}$ and $S$, respectively, and the width of the active zone is $W_{*}$, see Fig. 11 .

We first consider the shoreline response to sea level rise according to the Bruun Rule. The profile is considered to move landward and

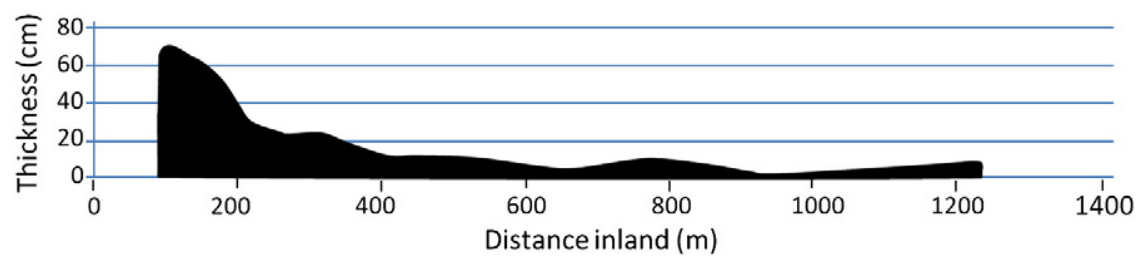

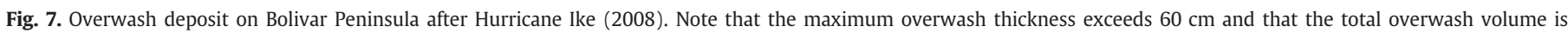
approximately $80 \mathrm{~m}^{3} / \mathrm{m}$ (adapted from Williams, 2010). 


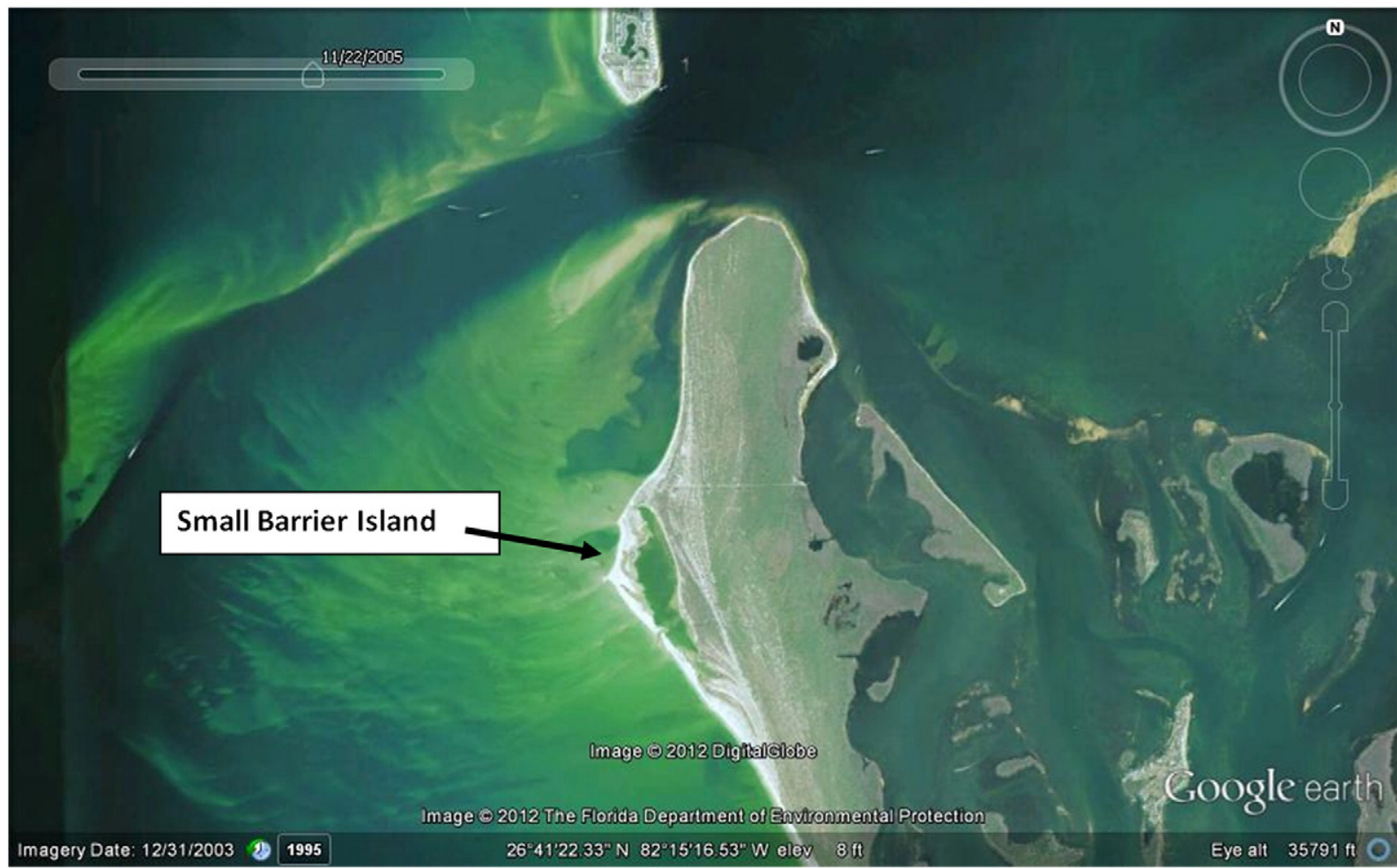

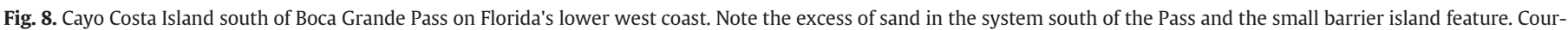
tesy of Google Earth.

upward in response to local sea level rise (SLR) without change of form. The equation for shoreline recession is (Edelman, 1972; Dean and Dalrymple, 2002):

$\frac{d R}{d t}=\frac{W_{*}}{h_{*}+B(t)} \frac{d S}{d t}=\frac{W_{*}}{h_{*}+B_{0}-S} \frac{d S}{d t}$

which accounts for the diminishing berm height as sea level rises (not normally taken into consideration in the application of the Bruun Rule). The solution to this equation considering only seaward transport is:

$R=W_{*} \ln \left(\frac{h_{*}+B_{o}}{h_{*}+B_{0}-S}\right) \approx S \frac{W_{*}}{h_{*}+B_{o}}$

which reduces to the original Bruun Rule for small $S$.

Note that if landward deposition occurs with volume $V_{D}$ (units of volume per unit beach length), replace $W_{*}$ by $W_{*}+V_{D} / S$ in the above so that the solution for $R$ is

$R=\left(W_{*}+V_{D} / S\right) \ln \left(\frac{h_{*}+B_{0}}{h_{*}+B_{o}-S}\right) \approx S \frac{W_{*}+V_{D} / S}{h_{*}+B_{o}}$.

It is noted that this relationship includes an additive term to the original Bruun Rule, thus landward transport increases the shoreline retreat. Application of Eq. (5) only requires quantification of the volume per unit length of the landward deposition, $V_{D}$. The deposition does not need to be of a rectangular cross-section as depicted in Fig. 11 or as shown in subsequent figures. Only landward transport (negative) will occur for recession values greater than the critical value, $R_{\text {Crit }}$, defined as:

$R_{\text {Crit }}=W_{*}-\left(\frac{h_{*}-S}{A}\right)^{3 / 2}$

and the associated depositional volume is:

$V_{\text {Crit }}=R B_{o}-S W_{*}+\frac{3}{5} A\left(W_{*}^{5 / 3}-\left(W_{*}-R\right)^{5 / 3}\right)$.

The equations for sand volumetric transport $V(y)$ (volume per unit length) past a location, $y$ are:

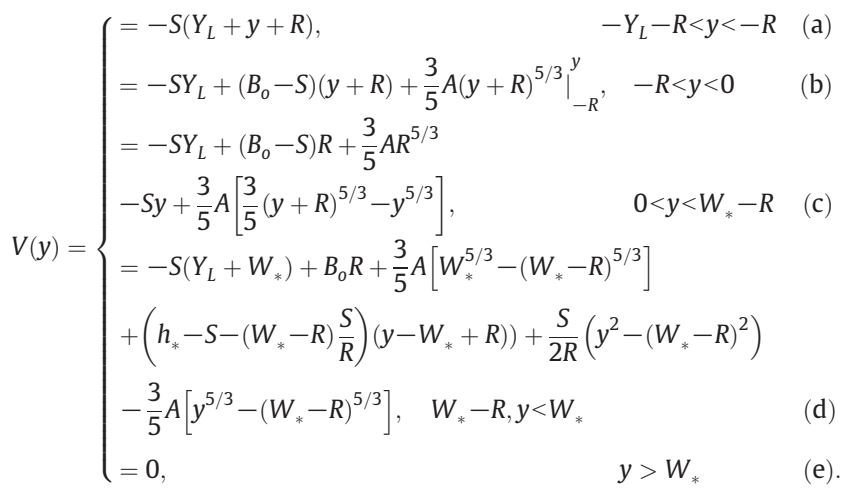

Appendix A outlines the derivation of Eq. (8). Note if Eq. (8d) is evaluated at $y=W_{*}$, the volume should be zero. To evaluate this, we set $y=W^{*}$ and $V=0$ with the following result

$R=S \frac{Y_{L}+W_{*}}{h_{*}+B_{0}-\frac{S}{2}}$ 

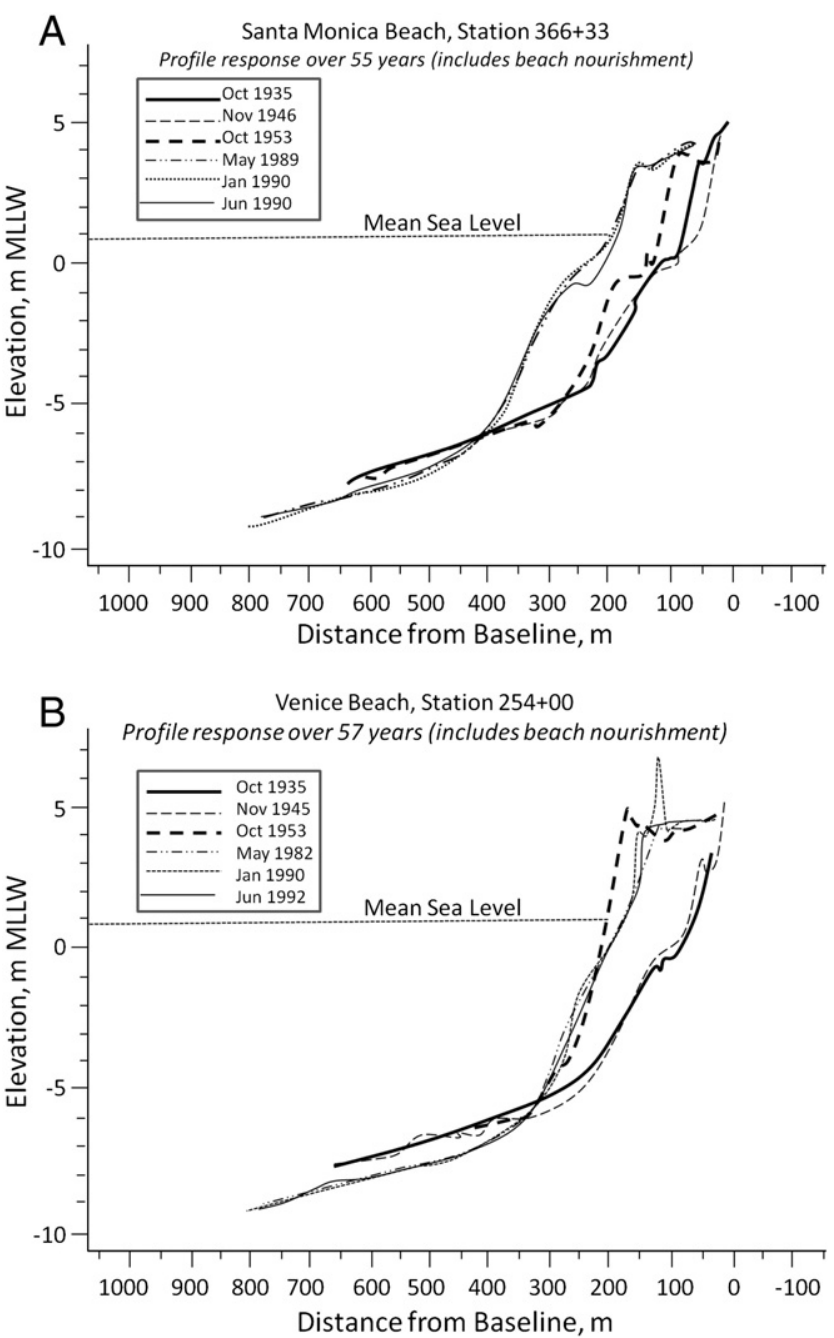

Fig. 9. Deepening of profiles in Santa Monica Bay, a. Santa Monica Beach (nourishment in 1947 and 1964); b. Venice Beach (nourishment in 1947 and 1964). Adapted from Leidersdorf et al. (1993).

where $Y_{L}=V_{D} / S$; however, it is not necessary that the thickness of the deposit be equal to the magnitude of $S$. The above equation is recognized as an approximation of

$R=\left(W_{*}+V_{D} / S\right) \ln \left(\frac{h_{*}+B_{o}}{h_{*}+B_{0}-S}\right)$.

The following three examples illustrate profile changes and associated volumetric transport associated with sea level rise with and without overwash. The characteristics of these three examples are presented in Table 1. Examples 1 and 2 are for cases in which no landward transport and only landward transport occur, respectively; Example 3 has both landward and seaward transports. Note that Eq. (8) applies for all three examples.

The results for these three examples are presented in Figs. 12, 13 and 14 with the lower panels presenting the pre- and post- response profile characteristics and the upper panels presenting the volumetric transport past a particular location associated with the profile response.

\section{Discussion}

Literature review and consideration of the processes associated with long-term response to sea level rise show that, although some investigations provide support to the Bruun Rule, there are clearly essential processes that are not included in the Bruun Rule, including

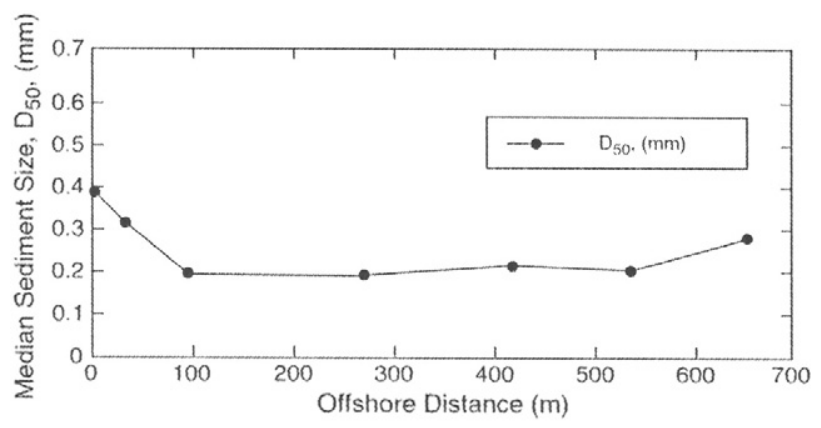

(a) Averages for 165 Florida East Coast Proliles

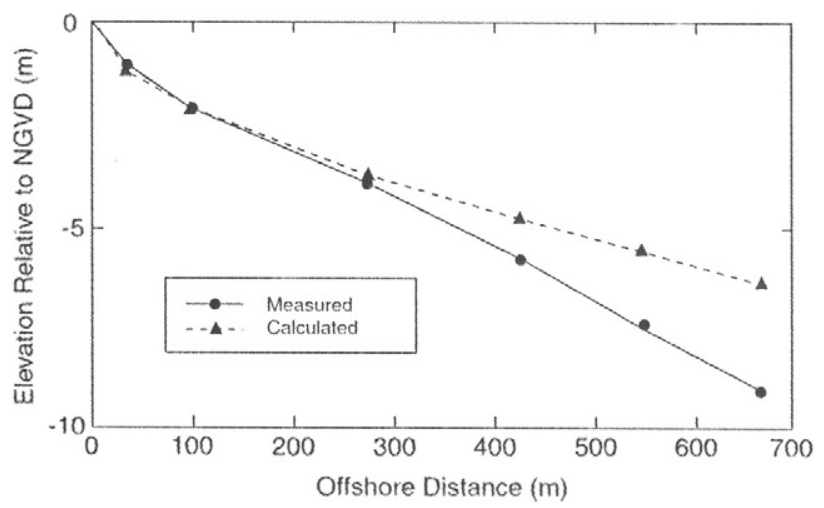

Fig. 10. Distribution of sediment sizes (a) across average profile (b, measured profile and calculated EBP). From Dean and Charles (1994).

landward sediment transport due to overwash and Aeolian processes. For purposes herein, we consider those profiles characterized by a balanced or an excess of sand.

For profiles in which both landward and seaward transports occur, the implication of the modified Bruun Rule is that beach recession $R$ will be greater than with the original Bruun Rule, as the modification represents an additive term (Eq. (5)) to the Bruun Rule. In applying the modified Bruun Rule, there is the additional need to quantify the landward depositional volume or equivalently, if the thickness is considered to be the sea level rise since the last overwash, the cross-shore distance of the overwash. For those beaches backed by high topography where the dry beach extends from the water line to the base of the high topography, the cross-shore distance is well-defined. However, for other cases, additional information is required. It is suggested that this information must be developed based on field measurements in which the three dimensional geometry of the overwash is quantified.

\section{Summary}

Nearshore processes in the presence of relative sea level rise have been examined and show that profile response must include landward

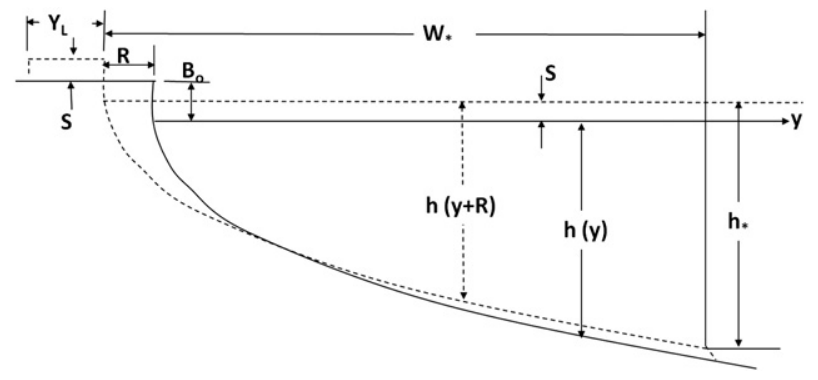

Fig. 11. Variables in the Modified Bruun Rule. 
Table 1

Characteristics of three examples.

Sea level rise $=0.5 \mathrm{~m}$ for all three examples.

\begin{tabular}{|c|c|c|c|c|c|c|}
\hline \multirow[t]{2}{*}{$\begin{array}{l}\text { Example and direction } \\
\text { of transport }^{\mathrm{a}}\end{array}$} & \multirow[t]{2}{*}{$h *(\mathrm{~m})$} & \multirow[t]{2}{*}{$B_{o}(\mathrm{~m})$} & \multirow[t]{2}{*}{$\begin{array}{l}A \\
\left(\mathrm{~m}^{1 / 3}\right)\end{array}$} & \multicolumn{2}{|c|}{$\begin{array}{l}\text { Overwash deposit } \\
\text { characteristics }\end{array}$} & \multirow[t]{2}{*}{$R(\mathrm{~m})$} \\
\hline & & & & $\begin{array}{l}\text { Length } \\
(\mathrm{m})\end{array}$ & $\begin{array}{l}\text { Thickness } \\
(\mathrm{m})\end{array}$ & \\
\hline 1 (S only, Eq. (4)) & 6 & 2 & 0.1 & 0 & 0 & 29.99 \\
\hline 2 (L only, Eq. (6)) & 6 & 2 & 0.1 & 416.9 & 0.5 & 56.90 \\
\hline 3 (L\&S, Eq. (5)) & 6 & 2 & 0.1 & 135.0 & 0.5 & 38.71 \\
\hline
\end{tabular}

a $\mathrm{S}=$ seaward transport; $\mathrm{L}=$ landward transport; $\mathrm{L} \& \mathrm{~S}=$ both landward and seaward transport.

transport of sediments on most, if not all, sandy beach profiles. These include direct observation of washover and/or Aeolian deposits, offshore profile deepening and lack of predicted offshore sediment deposit thicknesses and sizes. Profile response to relative sea level rise depends primarily on whether: (1) a profile has an excess or deficit of sand, and (2) the storms considered are sufficiently severe to cause overwash. However, over the long term, only the first of these two criteria will govern in the presence of sea level rise. As sea level continues to rise, overwash will occur due to less intense storm conditions. Although the original Bruun Rule predicted that the response to sea level rise was shoreline recession with only seaward sediment transport, it is clear that under many settings of relevance landward transport occurs.
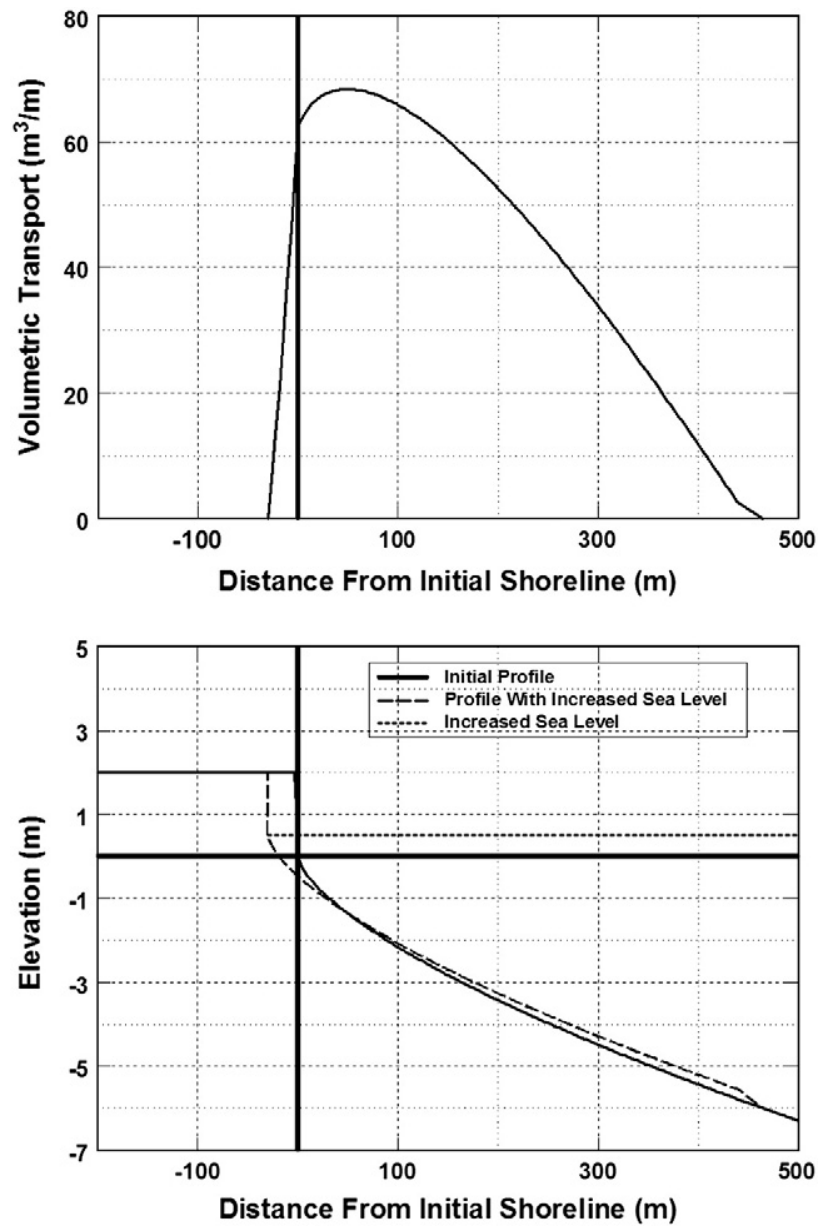

Fig. 12. Example 1 volumetric transport (upper panel) and profile changes (lower panel). Note that for this example, only seaward transport occurs (Bruun Rule).
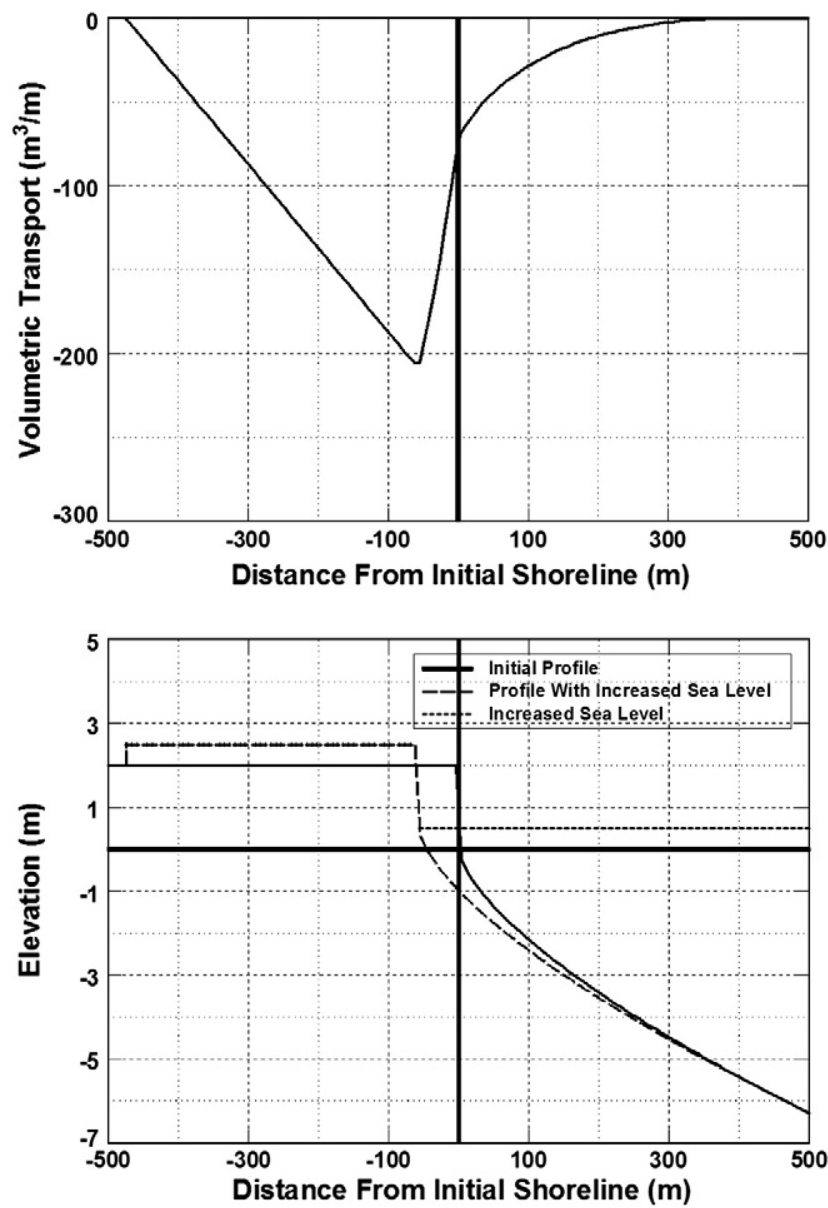

Fig. 13. Example 2 volumetric transport (upper panel) and profile changes (lower panel). For this example only landward transport occurs.

The modified Bruun Rule proposed here includes an additive term to the original Bruun Rule, thereby maintaining the form of the Bruun Rule and increasing the shoreline retreat due to sea level rise. The concept of only seaward transport due to sea level rise has been questioned by a number of investigators. The concept of landward sediment transport is supported in a broad sense by the recognition that many of our modern barrier islands were constructed by onshore sediment transport during the recent so-called still stand of sea level over the last 7000 to 8000 years (the de Beaumont hypothesis).

Idealized equilibrium beach profiles are applied to illustrate examples of profile response to sea level rise for several combinations ranging from full seaward sediment transport to full landward transport.

The recognition that landward transport is essential to the quantification of profile response to sea level rise places greater emphasis on field studies to document response to storms, in particular the volume and distribution of landward and seaward deposits resulting from extreme events or those associated with Aeolian processes. Lidar and Ground Penetrating Radar should be effective in conducting the necessary measurements. It is hoped that this paper will contribute to efforts that will advance the understanding of landward sediment transport.

Finally, lacking a capability to quantify long-term landward transport rates for the prediction of future shoreline response to sea level rise, one obvious approach is to develop and apply historic shoreline change rates on a local or regional basis. However, this does not provide a basis for large-scale, long-time frame considerations of the consequences and optimal management strategies in response to various scenarios of sea level rise. 

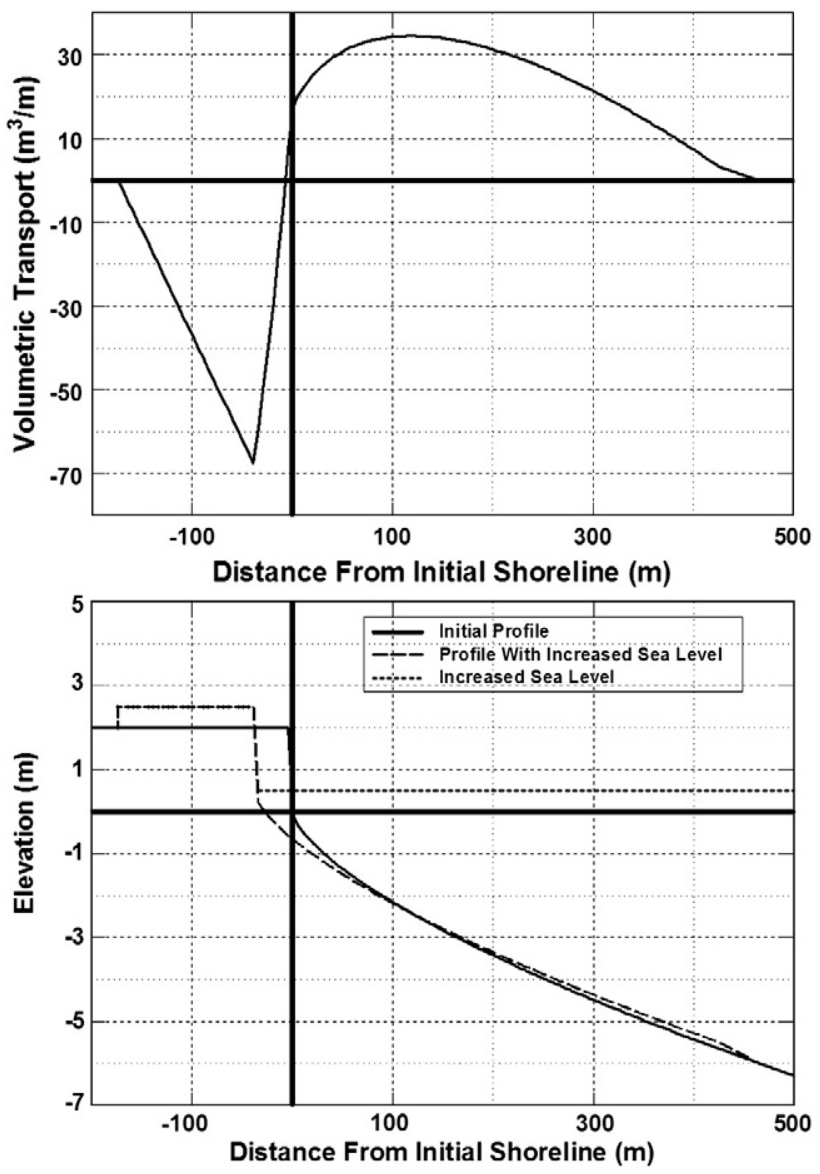

Fig. 14. Example 3 volumetric transport (upper panel) and profile changes (lower panel). For this example, both seaward and landward transport occur.

\section{Acknowledgements}

We appreciate suggestions and comments from Mr. Mark Gravens, U.S. Army Corps of Engineers (USACE), Dr. James Houston, Retired Emeritus, USACE, two anonymous reviewers and the Editor, who greatly improved the clarity of the manuscript. This work was conducted with partial funding (JDR) from the USACE's Coastal Inlets Research Program (CIRP).

\section{Appendix A. Derivation of equations}

This appendix describes derivation of Eq. (8a, b, c and d) in a series of steps.

With knowledge of the required parameters $\left(V_{D}, B_{o}, W^{*}, h_{*}^{*} S\right)$, we calculate $R$ from Eq. (5). This allows complete specification of the geometries of the before and after profiles.

Calculation of $V(y)$ commences by applying the one-dimensional equation of conservation of sediment (Dean and Dalrymple, 2002),

$\frac{\partial q}{\partial y}+\frac{\partial z}{\partial t}=0$

in which $q$ is the cross-shore transport per unit beach length and is positive seaward, $z$ is the vertical position of the profile and is positive upwards, $t$ is the time and $y$ is defined as the cross-shore coordinate and is positive seaward as shown in Fig. 1.

Since the vertical positions of the two profiles have been established, $V(y)$ can be calculated; however, as indicated in Eq. (8), it is necessary to do this in five segments as the analytical representations of the profiles change from one segment to the next. Integrating Eq. (A-1) with respect to time

$$
\frac{\partial}{\partial y} \int_{t_{1}}^{t_{2}} q d t=-\frac{\partial}{\partial t} \int_{t_{1}}^{t_{2}} z d t
$$

or

$\frac{\partial V}{\partial y}=-\left[z_{2}-z_{1}\right]$

And integrating with respect to $y$,

$V\left(y_{2}\right)=V\left(y_{1}\right)-\int_{y_{1}}^{y_{2}}\left[z_{2}-z_{1}\right] d y$.

The computations are initiated for a value of $y$ where the transport is zero (i.e., at $y_{1}=-y_{L}-R$ )

$V\left(y=-y_{L}-R\right)=0$

and continued seaward for each of the five segments to the limit of profile change $y=W_{*}$.

\section{References}

Absalonsen, L., Dean, R.G., 2011. Characteristics of the shoreline change along Florida sandy beaches with an example for Palm Beach County. Journal of Coastal Research 13 (6A), 16-26.

Bruun, P., 1954. Coast erosion and the development of beach profiles. Beach Erosion Board Technical Memorandum 44.US Army Corps of Engineers, Washington DC (79 pp.).

Bruun, P., 1962. Sea level rise as a cause of shore erosion. Journal of Waterways and Harbors Division, ASCE 88, 117-130.

Bruun, P., 1988. The Bruun Rule of erosion by sea level rise: a discussion on large-scale two- and three-dimensional usages. Journal of Coastal Research 4, 627-648.

Bruun, P., 1993. Discussion of Dubois, R.N., 1992. Journal of Coastal Research 9 (1), 282-284.

Cooper, J.A.G., Pilkey, O.H., 2004. Sea-level rise and shoreline retreat: time to abandon the Bruun Rule. Global and Planetary Change 43, 157-171.

Davidson-Arnott, R.G.D., 2005. A conceptual model of the effects of sea level rise on sandy coasts. Journal of Coastal Research 21 (6), 1166-1172.

Davis, R.A., 1994. Barrier islands systems-a geologic overview. In: Davis, R.A (Ed.), Chapter 1 in Geology of Holocene Barrier Island Systems. Springer, Verlag, pp. 1-46.

de Beaumont, L.E., 1845. Septieme lechón. In: Bertrand, P. (Ed.), Lecons de geologie pratique, pp. 221-252 (Paris, France).

Dean, R.G., 1977. Equilibrium beach profiles: U.S. Atlantic Gulf Coasts. Ocean Engineering Technical Report \#12.University of Delaware, Newark, Delaware.

Dean, R.G., 1990. Beach Response to Sea Level Change. In: Le Mehaute, B., Hanes D.M. (Eds.), Ocean Engineering Science, v. 9 of The Sea. Wiley Inc., New York, pp. 869-887.

Dean, R.G., 1991. Equilibrium beach profiles: characteristics and applications. Journal of Coastal Research 7 (1), 53-84.

Dean, R.G., Charles, L., 1994. Equilibrium beach profiles: concepts and evaluation. Report No. UFL/COEL-94-013.Coastal and Oceanographic Engineering Department, University of Florida, Gainesville, Florida.

Dean, R.G., Dalrymple, R.A., 2002. Coastal Processes with Engineering Applications Cambridge University Press, Cambridge, UK (475 pp.).

Dean, R.G., Maurmeyer, E.M., 1983. Models for beach profile response. In: Komar, P.D. (Ed.), Handbook of Coastal Processes and Erosion. : Boca Raton. CRC Press, Florida, pp. 151-166.

Dolan, R., Hayden, B., May, S., 1983. Erosion of the United States shorelines. In: Komar P.D. (Ed.), Handbook of Coastal Processes and Erosion. Boca Raton. CRC Press, Florida, pp. 285-299.

Donnelly, C., 2007. Morphology change by overwash: establishing and evaluating predictors. Journal of Coastal Research, SI 50, 520-526.

Donnelly, C., 2008. Coastal Overwash: Processes and Modeling. Ph. D. Dissertation University of Lund, Sweden (52 pp.).

Donnelly, C., Kraus, N.C., Larson, M., 2006. State of knowledge on measurement and modeling of coastal overwash. Journal of Coastal Research 22 (4), 965-991.

Dubois, R.N., 1990. Barrier-beach erosion and rising sea level. Geology 18, 1150-1152.

Dubois, R.N., 1992. A re-evaluation of Bruun's rule and supporting evidence. Journal of Coastal Research 8, 618-628.

Dubois, R.N., 1993. Reply to discussion by Per Bruun (1993) on the paper by Dubois, R.N., 1992. A re-evaluation of Bruun's rule and supporting evidence. Journal of Coastal Research 8 (3), 618-628. 
Edelman, T., 1972. Dune erosion during storm conditions. Proceedings, 13th International Conference on Coastal Engineering. American Society of Civil Engineers, pp. 1305-1312.

Everts, C.H., 1985. Sea level rise effects. Journal of Waterway, Port, Coastal and Ocean Engineering, American Society of Civil Engineers 111 (6), 985-999.

Finkl, C.W., Benedet, L., Andrews, J.L., 2005. Interpretation of seabed geomorphology based on spatial analysis of high-density airborne laser bathymetry. Journal of Coastal Research 21, 501-514.

Hands, E.B., 1979. Changes in rates of shore retreat, Lake Michigan, 1967-1976. Coastal Engineering Research Center, Technical Memorandum No. 79-4. (71 pp.).

Hands, E.B., 1980. Prediction of shore retreat and nearshore profile adjustments to rising water levels on the Great Lakes. Coastal Engineering Research Center, Technica Memorandum No. 80-7. (119 pp.).

Hands, E.B., 1983. The Great Lakes as a test model for profile response to sea level changes. In: Komar, P.D. (Ed.), Handbook of Coastal Processes and Erosion. CRC Press, Boca Raton, Florida, pp. 167-189.

Inman, D.L., Elwany, M.H.S., Jenkins, S.A., 1993. Shoreline and bar-berm profiles on ocean beaches. Journal of Geophysical Research 98 (C10), 18,181-18,199.

Kaplin, P.A., Selivanov, A.O., 1995. Recent coastal evolution of the Caspian Sea as a natural model for coastal responses to the possible acceleration of global sea-level rise. Marine Geology 124, 161-175.

Khalil, S.M., 2008. The use of sand fences in barrier island restoration: experience on the Louisiana coast. ERDC TN-SWWRP-08-4.U.S. Army Engineer Research and Development Center, Vicksburg, Mississippi (https://swwrp.usace.army.mil).

Khalil, S., Knotts, C.P., Tate, B., 2006. Restoration of Louisiana barrier islands: engineering approaches to hazard mitigation by modulating coastal environments. Proceedings, International Conference on Coastal Engineering, World Scientific.

Kobayashi, N., Tega, Y., Handcock, M.W., 1996. Wave reflection and overwash of dunes. Journal of Waterway, Port, Coastal, and Ocean Engineering 122 (3), 150-153.

Larson, M., Donnelly, C., Jimenez, J., Hanson, H., 2009. Analytical model of beach erosion and overwash during storms, proceedings of ICE. Maritime Engineering 162 (3), $115-125$.

Leatherman, S.P., Zhang, K., Douglas, B.C., 2000. Sea level rise shown to drive coastal erosion. Eos, Transactions of the American Geophysical Union 81 (6), 55-57.

Leidersdorf, C.J., Hollar, R.C., Woodell, G., 1993. Beach enhancement through nourishment and compartmentalization: the recent history of Santa Monica Bay. In: Stauble, D.K., Kraus, N.C. (Eds.), Beach Nourishment Engineering and Management Considerations. American Society of Civil Engineers, pp. 71-85.

Leidersdorf, C.J., Hollar, R.C., Woodell, G., 1994. Human intervention with the beaches of Santa Monica Bay, California. Shore and Beach 62 (3), 29-38.

Lippman, T.C., Holman, R.A., 1990. The spatial and temporal variability of sand bar morphology. Journal of Geophysical Research 95 (C7), 11,575-11,590.

List, J.H., Sallenger, A.H., Hansen, M.E., Jaffee, B.E., 1997. Accelerated relative sea-level rise and rapid coastal erosion: testing a causal relationship for the Louisiana barrier islands. Marine Geology 140, 347-363.

McCarty, E., 2009. A Case Study: The Impact of the 1962 Northeaster on Delaware's Atlantic Coast. MSc Thesis University of Delaware (163 pp.).

Mimura, N., Nobuoka, H., 1995. Verification of Bruun Rule for the estimate of shoreline retreat caused by sea-level rise. In: Dally, W.R., Zeidler, R.B. (Eds.), Coastal Dynamics 95. American Society of Civil Engineers, New York, pp. 607-616.
Moore, B.D., 1982. Beach Profile Evolution in Response to Changes to Water Level and Wave Height. M.Sc. thesis Department of Civil Engineering, University of Delaware, Newark, Delaware.

Morton, R.A., Sallenger Jr., A.H., 2003. Morphological impacts of extreme storms on sandy beaches and barriers. Journal of Coastal Research 19 (3), 560-573.

Park, Y.H., 2006. Overwash Induced by Storm Conditions. Ph. D. Dissertation Texas A and M University, College Station, Texas.

Pilkey, O.H. Davis, T.W 1987. An analysis of coastal recession models: North Carolina coast. In: Nummedal, D., Pilkey, O.H., Howard, J. (Eds.), Sea-level Fluctuations and Coastal Evolution, Tucson, Arizona: SEPM. Special Publication, 41, pp. 59-68.

Podufaly, E.T., 1962. Operation five-high. Shore and Beach 30 (2), 9-18.

Ranasinghe, R., Callaghan, D., Stive, M.J.F., 2012. Estimating coastal recession due to sea level rise: beyond the Bruun Rule. Climatic Change 110, 561-574. http:// dx.doi.org/10.1007/s10584-011-0107-8.

Robertson, W., Zhang, K., Finkl, C.W., Whitman, D., 2008. Hydrodynamic and geologic influence of event-dependent depth of closure along the South Florida Atlantic Coast. Marine Geology 252, 156-165.

Rosen, P.S., 1978. A regional test of the Bruun Rule on shoreline erosion. Marine Geology 26, M7-M16.

Sallenger Jr., A.H., 2000. Storm impact scale for barrier islands. Journal of Coastal Research 16 (3), 890-895.

Schwartz, M.L., 1965. Laboratory study of sea-level as a cause offshore erosion. Journal of Geology 73, 528-534.

Schwartz, M.L., 1967. The Bruun theory of sea-level rise as a cause of shore erosion. Journal of Geology 75, 76-92.

Schwartz, M.L., 1987. The Bruun Rule-twenty years later. Journal of Coastal Research 3, ii-iv. SCOR Working Group 89, 1991. The response of beaches to sea level changes: a review of predictive models. Journal of Coastal Research 7, 895-921.

Shaffer, T., 2012. REUTERS, October 30, 2012. http://www hurricanesandynews.com/ blog/2012/10/30/14-stunning-sandy-statistics/595/piles-of-sand-and-debris-fromhurricane-sandy-cover-the-parking-meters-on-the-seawall-along-beach-avenue-incape-may (accessed December 28, 2012).

Shepard, F.P., 1950. Beach cycles in Southern California. U.S. Army Corps of Engineers, Beach Erosion Board Technical Memo No. 20.

Sonu, C.J., 1973. Three-dimensional beach changes. Journal of Geology 81, 42-64.

Stive, M.J.F., 2004. How important is global warming for coastal regions? An editorial comment, Climatic Change 64, 27-39.

Tarigan, A.M., Lee, S.C., Mehta, A.J., 1996. Recession of the muddy coast: a departure from the Bruun Rule? In: Lee, S.C., Hiew, K.L., Ong, S.H. (Eds.), Proceedings of the 10th Congress of the Asia and Pacific Division of IAHR. National Hydraulics Research Institute of Malaysia, Kuala Lumpur, pp. 468-477.

Tega, Y., Kobayashi, N., 2000. Dune profile evolution due to overwash. Proceedings, 27th Coastal Engineering Conference, American Society of Civil Engineering pp. 2634-2647.

Williams, P., 1978. Laboratory Development of a Predictive Relationship for Washover Volume on Barrier Island Coastlines. M.S. Thesis University of Delaware, Newark, Delaware.

Williams, H.L.F., 2010. Storm surge deposition by Hurricane Ike on the McFaddin National Wildlife Refuge, Texas: implications for paleotempestology studies. Journal of Foraminiferal Research 40 (3), 210-219.

Zhang, K., Douglas, B.C., Leatherman, S.P., 2004. Global warming and coastal erosion. Climactic Change 64, 41-58. 